\title{
Analisis Kesalahan Siswa Dalam Memecahkan Masalah Matematika Higher Order Thinking Skills (HOTS) Berdasarkan Kriteria Hadar Ditinjau Dari Kemampuan Awal Siswa
}

\author{
Erwinda Gracya Laman ${ }^{1, \text { a) }}$, Suradi ${ }^{1}$, dan Asdar $^{1}$ \\ ${ }^{1}$ Jurusan Matematika, Fakultas MIPA, Universitas Negeri Makassar \\ a)erwinda01@gmail.com
}

\begin{abstract}
Abstrak.Penelitian ini bertujuan untuk mengetahui deskripsi kesalahan siswa dalam memecahkan masalah matematika Higher Order Thinking Skills serta gambaran perbedaan kesalahan pada bidang geometri berdasarkan kriteria Hadar. Jenis penelitian ini adalah penelitian deskriptif menggunakan pendekatan kualitatif. Pengambilan subjek dilakukan dengan memberikan tes kemampuan awal kepada siswa kelas XII MIPA 3 yang kemudian dari hasil tersebut dipilih 6 subjek penelitian berdasarkan kategori yang ada. Instrumen yang digunakan adalah tes kemaтрuan awal yang memuat dari 30 butir soal, tes tertulis Higher Order Thinking Skills yang memuat 2 butir soal uraian dan pedoman wawancara. Kesalahan dianalisis menggunakan kategori kesalahan Hadar yang terdiri dari 6 kesalahan. Hasil penelitian menunjukkan bahwa, kesalahan yang terjadi adalah kesalahan menggunakan data, kesalahan menggunakan bahasa, kesalahan menggunakan logika untuk menarik kesimpulan, kesalahan menggunakan definisi atau teorema, penyelesaian tidak diperiksa kembali, dan kesalahan teknis. Subjek yang mengerjakan soal HOTS materi geometri cenderung melakukan kesalahan menggunakan logika dalam menarik kesimpulan, kesalahan menggunakan definisi atau teorema, dan kesalahan teknis. Hasil dari penelitian ini diharapkan dapat menambah wawasan tentang jenis kesalahan yang dilakukan siswa SMA pada materi geometri khususnya dalam mengerjakan soal level tingkat tinggi sehingga dalam proses pembelajaran kesalahan-kesalahan yang dilakukan dapat diminimalisir.
\end{abstract}

Kata Kunci: Kesalahan, Higher Order Thinking Skills, Kriteria Hadar.

\begin{abstract}
This study aims to know the description of students' error in solving Higher Order Thinking Skills (HOTS) mathematical problems and the description of errors differences of geometry based on Hadar criteria. This type of research is descriptive research using qualitative approach. Retrieval of the subject is performed by providing prior knowledge test of grade XII MIPA 3 , then from the result of the test selected 6 subjects based on existing categories. The instrument used in this research are prior knowledge test which contains 30 number of multiple choices, written tests of Higher Order Thinking Skills which contains 2 number of essay and interview guidelines. Errors are analyzed by using the Hadar error category which consists of 6 errors. The results of this research show that based on the Hadar error criteria, errors that occur are misused data, misinterpreted language, logically in valid inference, distorted theorem or definition, unverified solution, and technical error. Subjects who solving HOTS mathematics problem of geometry tend to make logically invalid inference, distorted definition or theorem, and technical errors. The results of this research are expected to add insight about the types of errors made by the students of senior high school in geometry topic, especially in solving higher order thinking skills problems so that the mistakes can be immediately minimized in the process of learning.
\end{abstract}

Keywords: Errors. Higher Order Thinking Skills. Hadar Criteria. 


\section{PENDAHULUAN}

Salah satu kompetensi dasar yang harus dimiliki siswa adalah pemecahan masalah. Hartono (2014) berpendapat bahwa pemecahan masalah merupakan bagian dari kurikulum matematika yang sangat penting. Hal ini dikarenakan siswa akan memperoleh pengalaman dalam menggunakan pengetahuan serta keterampilan yang dimiliki untuk menyelesaiakan soal. Krulik dan Rudnick (1999) mengemukakan bahwa pemecahan masalah merupakan proses individu menggunakan pengetahuan, keterampilan, dan pemahaman yang telah diperoleh untuk menyelesaikan masalah pada situasi yang tidak dikenalnya. Menurut Polya (1973) terdapat empat langkah dalam pemecahan suatu masalah meliputi memahami masalah, membuat rencana, melaksanakan rencana, dan memeriksa kembali. Melihat uraian penjelasan tentang pemecahan masalah di atas, sangat wajarlah jika kemampuan pemecahan masalah dikatakan sebagai salah satu kemampuan yang sangat penting untuk dikuasai oleh siswa khususnya dalam matematika.

Salah satu bagian dari kemampuan matematika adalah memecahkan masalah matematika. Genarsih (2015) menyatakan bahwa pemecahan masalah matematika adalah cara menemukan jawaban suatu permasalahan matematika agar siswa dapat memecahkan soal matematika tersebut. Bell (1978) menjelaskan bahwa pemecahan masalah matematika dapat membantu siswa dalam mengembangkan kemampuan mereka dan dapat membantu mereka dalam mengaplikasikan kemampuan pada berbagai situasi. Untuk membantu keterampilan pemecahan masalah matematika yang baik dibutuhkan beberapa kemampuan, salah satunya adalah kemampuan berpikir tingkat tinggi (Higher Order Thinking Skills).

Higher Order Thinking Skills (HOTS) adalah aktivitas berpikir siswa yang melibatkan level kognitif tingkat tinggi dari Taksonomi Bloom yang meliputi menganalisis, mengevaluasi, dan mencipta (Anderson \& Kratwohl,2015). HOTS adalah keterampilan yang lebih dari sekedar mengingat, memahami dan mengaplikasikan (Rosnawati, 2015). Sehingga soal HOTS merupakan instrumen atau alat pengukuran yang digunakan untuk mengukur kemampuan berpikir tingkat tinggi, yaitu kemampuan berpikir yang tidak sekadar mengingat, menyatakan kembali, atau merujuk tanpa melakukan pengolahan, akan tetapi kemampuan berpikir untuk menelaah informasi secara kritis, kreatif, dan mampu memecahkan masalah.

Dalam memecahkan masalah Matematika HOTS, seringkali siswa mengalami kesulitan dalam memecahkan masalah yang menimbulkan adanya kesalahan. Menurut Mullis, Martin, Ruddock, O'Sullivan dan Preuschoff (2009) tanpa pengetahuan dasar matematika yang baik, siswa akan mengalami kesulitan dalam mengingat fakta dasar matematika yang berguna untuk proses bepikir matematis. Akan tetapi, memiliki pengetahuan dasar yang baik belum tentu siswa tidak melakukan kesalahan dalam menyelesaikan soal HOTS. Pada pemecahan soal HOTS siswa dengan kemampuan matematika yang baik biasanya tidak lagi melakukan kesalahan data atau kesalahan kesimpulan, akan tetapi terjadi kesalahan pada pengembangan ide penyelesaian. Jika dikaitkan dengan jenis kesalahan, maka siswa yang memiliki kemampuan matematika yang baik yang sebenarnya tidak perlu lagi muncul pada saat menyelesaiakan soal HOTS. Sedangkan siswa yang tidak memiliki kemampuan yang baik biasanya dalam menyelesaiakan soal-soal HOTS, kesalahan yang dilakukan bukan hanya pada ide penyelesaian akan tetapi melakukan juga kesalahan data, kesalahan menyimpulkan atau kesalahan lainnya.

Penelitian ini bertujuan untuk mengetahui deskripsi kesalahan siswa dalam memecahkan masalah matematika HOTS berdasarkan kriteria Hadar. Penelitian Gais dan Afriansyah (2017) tentang analisis kemampuan siswa dalam menyelesaikan soal HOTS menyimpulkan bahwa faktor-faktor yang menyebabkan siswa keliru dalam menyelesaikan soal-soal HOTS diantaranya adalah kurang teliti dalam proses pengerjaan soal, kemampuan awal matematis siswa yang rendah, proses yang dilalui selama pembelajaran tidak maksimal, kurangnya pemahaman siswa terhadap soal, dan ketidaklengkapan dalam membaca soal. Selain itu, penelitian Komarudin (2016) tentang analisis kesalahan siswa dalam pemecahan masalah matematika dan memperoleh 
hasil penelitian yaitu terdapat 4 jenis kesalahan dalam menyelesaikan masalah pada materi peluang yaitu kesalahan memahami soal, kesalahan menyusun rencana, kesalahan melaksanakan rencana dan kesalahan dalam memeriksa solusi yang diperoleh.

Dalam penelitian ini kesalahan siswa yang dimaksud adalah jenis kesalahan yang diberikan oleh Hadar, Zaslavsky dan Inbar (1987) yang terdiri dari enam kesalahan, yaitu: (1) kesalahan menggunakan data, (2) kesalahan menginterpretasikan bahasa, (3) kesalahan menggunakan logika dalam menarik kesimpulan, (4) kesalahan menggunakan definisi atau teorema, (5) penyelesaian tidak diperiksa kembali, (6) kesalahan teknis.

Dalam pembelajaran matematika, ada faktor yang mempengaruhi proses pembelajaran yaitu faktor kemampuan awal. Faktor kemampuan awal siswa berbeda-beda satu sama lain. Gunowibowo (2008) mengatakan kemampuan awal adalah kemampuan yang telah melekat pada seseorang dan yang terkait dengan hal baru yang akan dipelajari selanjutnya. Soekamto dan Winataputra (1996) mengatakan bahwa kemampuan awal siswa tidak lain adalah kemampuan yang sudah dipunyai oleh siswa sebelum mengikuti pembelajaran yang akan diberikan oleh guru. Faktor kemampuan awal siswa dianggap paling berpengaruh, seperti diungkapkan Karso , Suyadi, Muhsetyo, Chadra, Widagdo dan Priatna (2008) faktor kemampuan awal siswa atau murid sebagai peserta didik merupakan faktor yang penting dalam proses belajar mengajar matematika. Faktor-faktor itu sepenuhnya tergantung pada siswa seperti kecerdasan, kesiapan, dan bakat anak.

\section{KAJIAN PUSTAKA}

\section{Pemecahan Masalah Matematika}

Kemampuan pemecahan masalah merupakan kompetensi dalam kurikulum matematika yang harus dimiliki siswa. Tim Instruktur jurusan Matematika (2008) menyatakan penyelesaian atau pemecahan masalah merupakan suatu proses mental yang tinggi dan kompleks, yaitu melibatkan visualisasi, imajinasi, abstraksi, dan asosiasi informasi-informasi yang diberikan. Pemecahan masalah sering disebut sebagai metode eksperimen, metode reflektif dan metode ilmiah (Priansa, 2015). Utari (2004) menegaskan bahwa pemecahan masalah dapat berupa menciptakan ide baru, menemukan teknik atau produk baru. pemecahan masalah adalah suatu tindakan (action) yang dilakukan guru agar para siswanya termotivasi untuk menerima tantangan yang ada pada pertanyaan atau soal dan mengarahkan para siswa dalamproses pemecahannya (Shadiq, 2009).

Ibrahim (Tambychik \& Meerah, 2010), menyatakan pemecahan masalah matematika bukanlah topik, tetapi proses yang mendasari seluruh program matematika yang secara kontekstual membantu konsep dan keterampilan untuk dipelajari. Suharna (2013) mengungkapkan bahwa pemecahan masalah matematika merupakan proses yang meliputi prosedur: memahami masalah, memikirkan rencana/ merencanakan, melaksanakan rencana, dan evaluasi terhadap hasil pemecahan. Pemecahan masalah dalam matematika adalah suatu aktivitas untuk mencari penyelesaian dari masalah matematika yang dihadapi dengan menggunakan semua pengetahuan matematika yang dimiliki oleh siswa (Widodo \& Sujadi, 2015). Bahkan di dalam pembelajaran matematika, selain pemecahan masalah mempunyai arti khusus, istilah tersebut juga mempunyai interpretasi yang berbeda. Misalnya menyelesaikan soal cerita atau soal yang tidak rutin dalam kehidupan sehari-hari.

\section{HOTS}

Keterampilan berpikir tingkat tinggi atau dalam bahasa inggrisnya Higher Order Thinking Skill adalah pola berpikir siswa dengan mengandalkan kemampuan untuk menganalisis, mencipta, dan mengevaluasi semua aspek dan masalah. Menurut Zaini (2015) berpikir tingkat tinggi 
adalah keterampilan berpikir yang mengkombinasikan antar berpikir kritis dan berpikir kreatif. HOTS merupakan aktivitas berpikir siswa yang melibatkan level kognitif tingkat tinggi dari Taksonomi Bloom yang meliputi menganalisis, mengevaluasi, dan mencipta (Anderson \& Krathwohl, 2015).

Dalam Taksonomi Bloom yang telah direvisi kemampuan berpikir tingkat tinggi melibatkan analisis $\left(\mathrm{C}_{4}\right)$, mengevaluasi $\left(\mathrm{C}_{5}\right)$, dan mencipta atau kreativitas $\left(\mathrm{C}_{6}\right)$ dianggap berpikir tingkat tinggi (Krathworl \& Anderson,2001).

Berikut penjelasan dimensi proses berpikir sebagaimana yang telah direvisi oleh Anderson dan Krathwohl, yang termasuk kemampuan berpikir tingkat tinggi sebagai berikut:

1. Menganalisis

Menganalisis yaitu memecahkan materi menjadi bagian-bagian pokok dan menggambarkan bagaimana bagian-bagian tersebut, dihubungkan satu sama lain maupun menjadi sebuah struktur keseluruhan atau tujuan (Kuswana, 2012). Pertanyaan analisis meminta siswa menyelesaikan permasalahan melalui pemeriksaan sistematik tentang fakta atau informasi (Sani, 2016) contoh kata kerja operasional yang digunakan pada level menganalisis yaitu: menganalisis, memecahkan, menegaskan, menelaah, dan mengaitkan.

2. Mengevaluasi atau menilai

Mengevaluasi yaitu melakukan evaluasi atau penilaian yang didasarkan pada kriteria dan atau standar (Kuswana, 2012). Pertanyaan ini meminta siswa membuat penilaian tentang suatu berdasarkan sebuah acuan atau standar (Sani, 2016). Contoh kata kerja pada level mengevaluasi yaitu: membandingkan, menyimpulkan, menilai, dan mengkritik.

3. Menciptakan (berkreasi)

Menempatkan bagian-bagian secara bersama-sama ke dalam suatu ide, semuanya saling berhubungan untuk membuat hasil yang baik (Kuswana, 2012). Pertanyaan ini meminta siswa untuk menemukan penyelesaian masalah melalui pemikiran kreatif (Sani, 2016). Contoh kata kerja operasional yang digunakan pada level menciptakan yaitu: mengatur, mengumpulkan, mengkategorikan, memadukan, dan menyusun.

\section{Kriteria Hadar}

Hadar, Zaslavsky, dan Inbar (1987) juga memberikan beberapa jenis kesalahan dalam menyelesaikan soal matematika, yang terdiri dari kesalahan menggunakan data,kesalahan menginterpretasikan bahasa, kesalahan menggunakan logika dalam menarik kesimpulan, kesalahan menggunakan definisi atau teorema, penyelesaian tidak diperiksa kembali, dan kesalahan teknis. Berikut penjelasan jenis kesalahan tersebut dalam tulisannya yang berjudul $A n$ Empirical Classification Model For Error in High School Mathematics:

1. Kesalahan menggunakan data

Kesalahan yang biasa terjadi pada kategori ini yaitu ketidaksesuaian siswa pada saat menggunakan data dari yang diketahui dengan yang ditangkap siswa. Kesalahan yang tercakup dalam kesalahan data yaitu: (1) kurang tepatnya siswa menyalin data dari soal, (2) siswa menambahkan data-data yang tidak sesuai, (3) mengabaikan data yang diberikan, (4) menyatakan suatu syarat yang tidak dibutuhkan, (5) mengartikan informasi tidak sesuai dengan teks sebenarnya, (6) mengganti syarat yang ditentukan dengan informasi lain yang tidak sesuai, dan (7) menggunakan nilai suatu variabel untuk variabel lain. Contohnya dalam geometri yaitu siswa salah menuliskan satuan suatu konsep matematika pada soal, misalnya panjang balok yang bersatuan meter dituliskan sentimeter.

2. Kesalahan menginterpretasikan bahasa

Karakteristik yang meliputi kesalahan ini yaitu: (1) kesalahan siswa mengubah bahasa sehari-hari kedalam bentuk persamaan matematika dengan arti yang berbeda, (2) menulis 
simbol dari suatu konsep dengan simbol lain yang artinya berbeda, dan (3) salah mengartikan grafik. Contohnya siswa tidak memahami kalimat atau istilah dalam soal.

3. Kesalahan menggunakan logika untuk menarik kesimpulan

Jenis kesalahan ini ialah kesalahan yang biasa dilakukan siswa pada saat menarik kesimpulan dari suatu masalah yang diberikan. Contohnya (1) Dari pernyataan implikasi $p \rightarrow q$, siswa menarik kesimpulan sebagai berikut: (a) bila $q$ diketahui maka $p$ pasti terjadi, (b) bila $p$ salah maka $q$ pasti juga salah. (2) Mengambil kesimpulan tidak benar, misalnya memberikan $q$ sebagai akibat dari $p$ tanpa dapat menjelaskan urutan pembuktian yang betul.

4. Kesalahan menggunakan defenisi atau teorema

Kesalahan ini biasa dilakukan siswa pada saat menyelesaiakan permasalahan yang dituntut menggunakan rumus, teorema, prinsip, ataupun defenisi matematika. Contohnya (1) menerapkan suatu teorema pada kondisi yang tidak sesuai misalnya kesalahan siswa dalam menerapkan teorema Phytagoras pada segitiga sebarang, (2) menerapkan sifat distributif untuk operasi yang bukan distributif misalnya (a) $\sin (\alpha+\beta)=\sin \alpha+\sin \beta$, (b) $(a+b)^{n}=a^{n}+b^{n}$, (3) tidak teliti atau tidak tepat dalam mengutip definisi, rumus, atau teorema. Misalnya (a) dalam persamaan parabola $a x^{2}+b x+c$ dimana $X_{\min }=-\frac{b}{a}$ sebagai pengganti $X_{\min }=-\frac{b}{2 a}$, (b) $(a-b)^{2}=a^{2}+2 a b-b^{2}$.

5. Penyelesaian tidak diperiksa kembali

Jenis kesalahan ini terjadi jika setiap langkah penyelesaian yang dilakukan oleh siswa tidak sesuai dengan hasil akhir. Jenis kesalahan ini terjadi ketika siswa mengerjakan soal secara terburu-buru sehingga pekerjaannya tidak dikoreksi kembali.

6. Kesalahan teknis

Kesalahan teknis yang mungkin terjadi ialah: (1) kesalahan perhitungan misalnya $7 \times 8=64$ (2) kesalahan dalam mengutip data, dan (3) kesalahan memanipulasi simbol-simbol aljabar misalnya $a-4 x b-4$ sebagai pengganti dari $(a-4)(b-4)$.

\section{METODE PENELITIAN}

Penelitian ini menggunakan pendekatan kualitatif. Subjek penelitian ini adalah 3 orang siswa kelas XII. Penetapan subjek penelitian ini berdasarkan hasil tes kemampuan awal yang diberikan. Terdapat tiga kategori kemampuan awal menurut Ratumanan dan Laurens (Maryam, 2016), kategori tersebut antara lain:

1. Kategori siswa dengan kemampuan awal tinggi (T) $(80 \leq x \leq 100)$

2. Kategori siswa dengan kemampuan awal sedang $(60 \leq x<80)$, dan

3. Kategori siswa dengan kemampuan awal rendah $(x<60)$.

Siswa yang telah dikelompokkan tadi kemudian diambil masing-masing satu untuk mewakili tiap-tiap kategori kemudian diberikan soal HOTS materi geometri. Setelah itu, siswa tersebut diwawancara terkait dengan jawaban yang sudah mereka tuliskan dan menganalisis kesalahan yang mereka lakukan.

Teknik pengumpulan data dalam penelitian ini meliputi: (1) Tes kemampuan awal matematika, (2) Tes soal HOTS, dan (3) Wawancara. Tes kemampuan matematika diberikan untuk mengetahui pemahaman awal siswa terhadap materi geometri guna untuk mengambil subjek penelitian yang kemudian akan diberikan soal matematika HOTS. Sedangkan tes soal HOTS yang dimaksud dalam penelitian ini adalah tes tertulis dalam bentuk uraian materi geometri. Tes ini bertujuan untuk mengungkap kesalahan-kesalahan siswa dalam memecahkan masalah matematika HOTS materi geometri. Setelah menyelesaikan soal pada tes tersebut, dilakukan wawancara sebagai alat triangulasi jawaban yang ditulis oleh subjek penelitian untuk mempelajari dan menelusuri kesalahan subjek dalam menyelesaikan soal yang diberikan. 
Instrumen yang digunakan telah divalidasi oleh 2 orang validator. Keabsahan data dilakukan dengan triangulasi teknik yaitu membandingkan data yang diperoleh dari tes soal HOTS dengan data yang diperoleh dari wawancara.

Analisis data dalam penelitian ini meliputi: (1) Analisis data kemampuan awal matematika, (2) Analisis hasil tes soal HOTS materi geometri, dan (3) Analisis wawancara yang terdiri dari tiga langkah (Miles, Huberman, \& Saldana, 2014), yaitu kondensasi data, penyajian data, dan penarikan kesimpulan.

\section{HASIL DAN PEMBAHASAN}

Rincian masing-masing subjek yang terpilih disajikan dalam Tabel 1.

TABEL 1. Penetapan Subjek Penelitian Subjek

\begin{tabular}{ccccc}
\hline No & Inisial Siswa & Kemampuan Awal & Skor Tes & Kode Siswa \\
\hline 1 & AT & Tinggi & 83 & S1 \\
2 & AHS & Sedang & 63 & S2 \\
3 & MMAN & Rendah & 16 & S3 \\
\hline
\end{tabular}

\section{Kesalahan Subjek Kemampuan Awal Matematika Tinggi}

Pada Gambar 1, terlihat bahwa subjek telah menuliskan informasi diketahui dan ditanyakan pada soal (S1-T21). Subjek juga menyelesaikan soal tersebut dengan menggunakan langkahlangkah yang sistematis. Tetapi pada langkah terakhir subjek melakukan kesalahan perhitungan dalam menentukan biaya sehingga subjek mendapatkan biaya sebesar $R p 120.960 .00,00$ (S1T28) yang seharusnya $R p$ 17.280.000. Setelah dikonfirmasi melalui wawancara, ternyata subjek tidak menyadari kesalahan yang dilakukannya (Transkrip 1)

\section{Transkrip 1}

$P \quad$ : Setelah didapatki itu luas segiempat dek, apa lagi langkah selanjutnya dek?

S2-W211 : $\quad$ Kan disoal itu kak yang ditanyakan itu biayanya, jadi selanjutnya itu biaya rumput permeternya dikali dengan luasnya dan hasilnya Rp.120.960.000

$P \quad$ : Menurutmu benarmi ini jawabnta dek? Benar mi cara perhitungan ta?

\section{S2-W212 : Benarmi menurutku kak}

Transkrip 1 menunjukkan bahwa benar subjek tidak menyadari kesalahan perhitungan yang dilakukannya dan meyakini jika jawabannya benar (S2-W211). Sehingga dapat dikatakan bahwa subjek melakukan kesalahan teknis dalam memecahkan masalah HOTS bidang geometri.

Pada Gambar 2, terlihat bahwa subjek telah menuliskan diketahui dan ditanyakan pada soal (S2-T21). Subjek juga telah mendapatkan persamaan garis dari informasi yang diketahui dari soal, tetapi subjek tidak menuliskan proses dalam mendapatkan nilai $x$ dan $y$ (S2-T22). Kemudian, subjek menentukan luas bangun segiempat dengan menjumlahkan luas persegi dan satu luas segitiga. Jadi, jumlah luas bangun persegi dan sebuah segitiga itulah yang menjadi luas bangun segiempat pada gambar yang diarsir di soal (S2-T26). Namun setelah dikonfirmasi melalui wawancara, ternyata subjek tidak menyadari kesalahannya (Transkrip 2) 


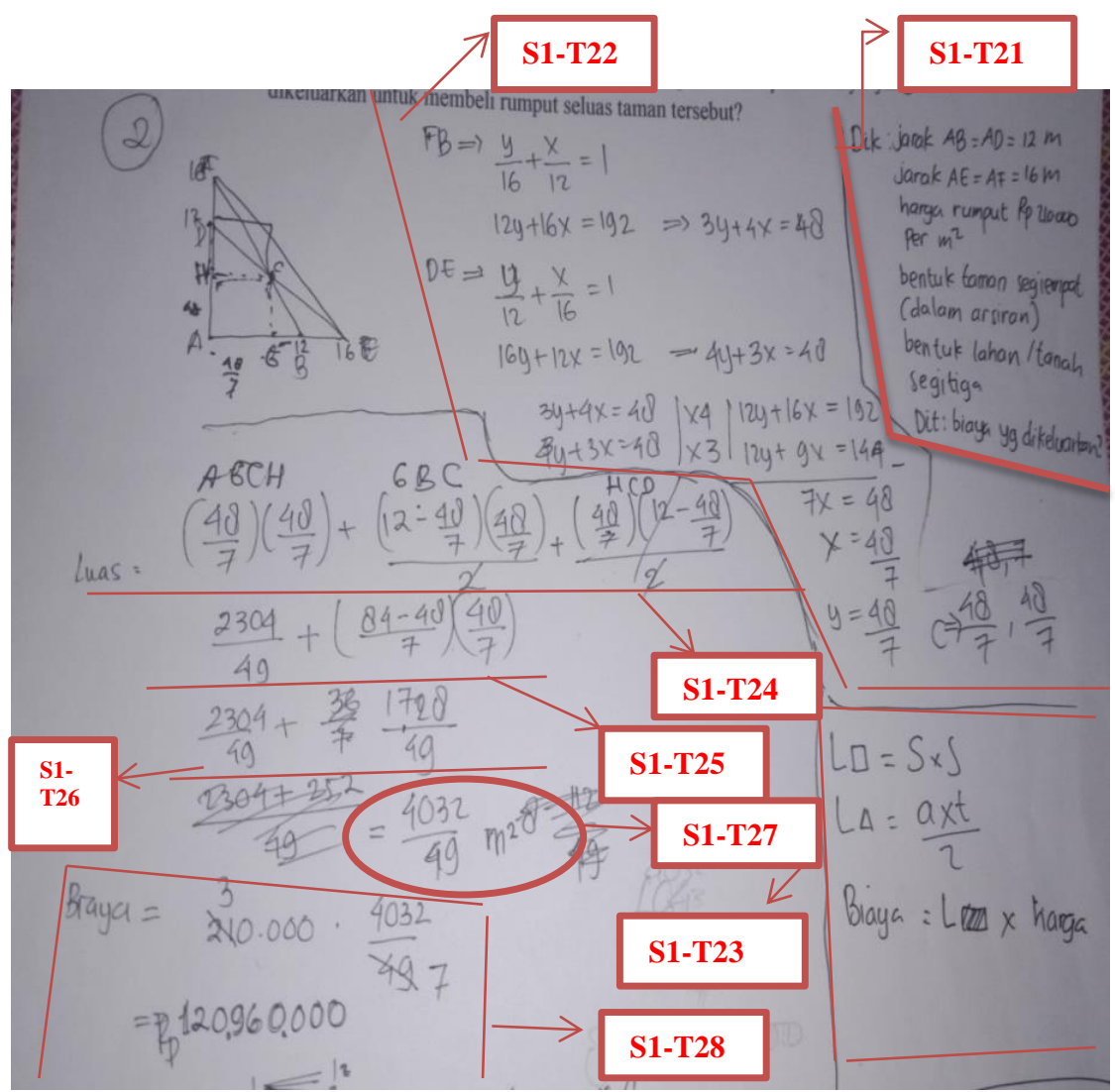

GAMBAR 1. Paparan hasil tes HOTS subjek dengan kemampuan awal matematika tinggi (AT)

\section{Kesalahan Subjek Kemampuan Awal Matematika Sedang}

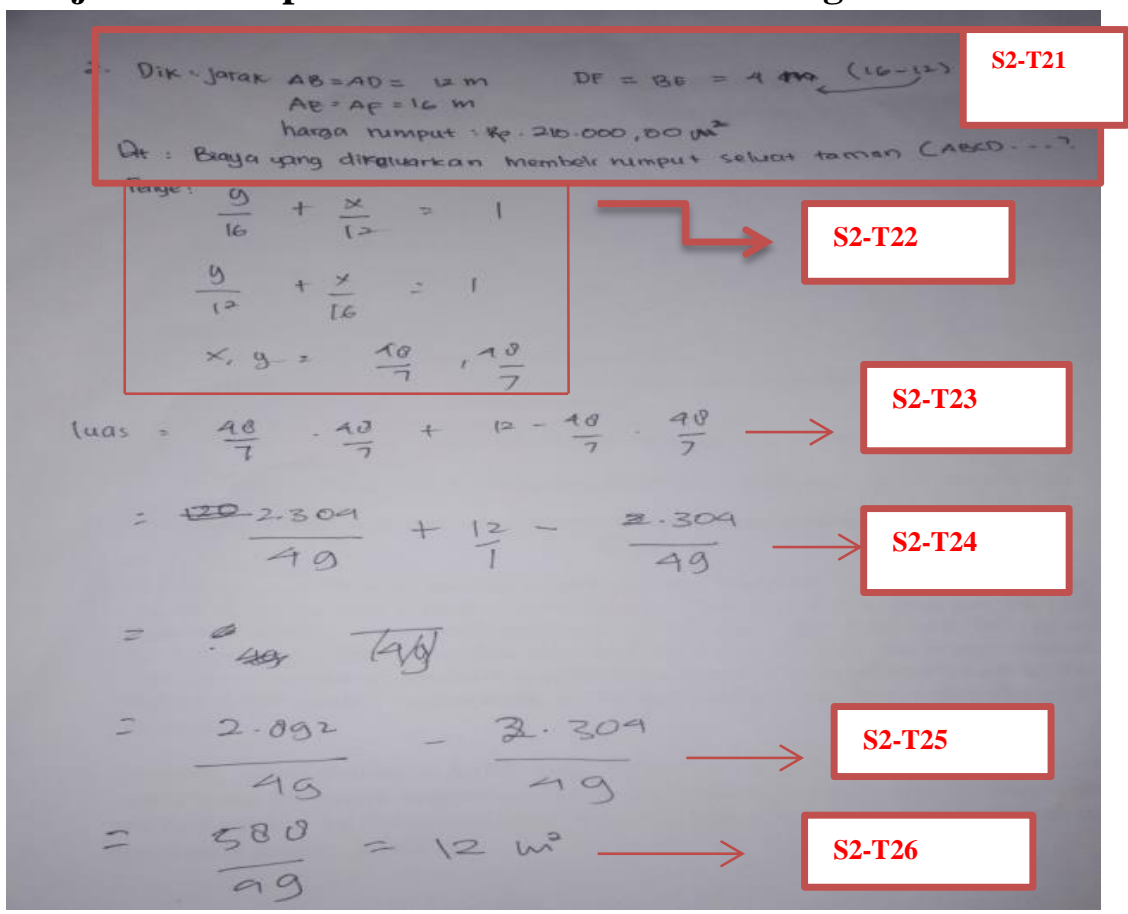

GAMBAR 2. Paparan hasil tes HOTS subjek dengan kemampuan awal matematika sedang (AHS) 


\section{Transkrip 2}

$P \quad$ : Ini maksudku dek darimana ki dapat ide buat persamaan begini $\frac{y}{16}+\frac{x}{12}=1$ $\operatorname{dan} \frac{y}{12}+\frac{x}{16}=1$ ?

S2-W215 : Hmmm...persamaan garisnya ji iya itu kak berdasarkan informasi dari soal, pake ki persamaan garis kak untuk tentukan itu persamaan. Setelah didapat itu persamaan kana da 2 toh kak, dieliminasi mi untuk dapat $x$ dan $y$. Ini nilai $x$ dan y digunakan nanti untuk cari panjang garis yang lain pada bangun di soal kak. Tapi saya tidak tulis cara mengeliminasinya kak karena buru-buru ma kak

$P \quad: \quad$ Terus dek, darimana ki dapat itu Luas $=\frac{48}{7} x \frac{48}{7}+12-\frac{48}{7} \cdot \frac{48}{7}$ ?

S2-W219 : $\quad$ Oh itu kak, sebenarnya $\frac{48}{7} x \frac{48}{7}$ luas persegi terus itu $12-\frac{48}{7} \cdot \frac{48}{7}$ luasnya segitiga kan untuk cari luasnya itu bangun yang diarsir luas persegi ditambahkan luas satu segitiga, dan hasilnya itu saya dapat kak $12 \mathrm{~m}^{2}$.

Transkrip 2 menunjukkan bahwa benar subjek tidak menuliskan proses dalam menentukan nilai $x$ dan . Subjek kemudian menentukan luas daerah yang diarsir dengan menjumlahkan luas persegi dan luas satu segitiga. Subjek melakukan kesalahan dalam mengambil kesimpulan dimana subjek membagi dua daerah tersebut menjadi persegi dan sebuah segitiga untuk mendapatkan total luasnya dan tidak menyadari kesalahannya (S2-W219). Sehingga dapat dikatakan bahwa subjek melakukan kesalahan menggunakan logika dalam menarik kesimpulan dalam memecahkan masalah HOTS bidang geometri.

Pada Gambar 2, terlihat bahwa subjek tidak menuliskan rumus mencari luas persegi dan untuk mencari luas segitiga dalam pemyelesaian soal. Dalam penerapan rumus untuk mencari luas segitiga subjek hanya menerapkannya dalam bentuk axt (S2-T23). Setelah dikonfirmasi melalui wawancara subjek menyadari kesalahannya dalam menerapkan rumus luas segitiga dan lupa menuliskan rumus luas persegi dan luas segitiga (Transkrip 3).

\section{Transkrip 3}

$P$

Kenapa rumusnya tidak ditulis dek?

S2-W221 : Hehe lupa ka kak, dan kehabisan waktu mi ka

$P$

Waduh...Hmm terus itu luas segitiga kan $\frac{a x t}{2}$ kenapa di jawaban ta tidak ada per duanya?

$S 2-W 222$ Astaga, iya di kak.. baru ka perhatikan, salah i kak seharusnya ada per duanya kak. Harusnya $\frac{a x t}{2}$ bukan a $x t$ kak

Transkrip 3 menunjukkan bahwa benar subjek lupa dalam menuliskan rumus mencari luas persegi dan luas segitiga (S2-W221), serta subjek menyadari bahwa penerapan rumus luas segitiga yang dituliskannya salah yaitu $a x t$ dan seharusnya $\frac{a x t}{2}$ (S2-W22). Sehingga dapat dikatakan bahwa subjek melakukan kesalahan menggunakan definisi atau teorema dalam memecahkan masalah HOTS bidang geometri.

Transkrip 4 menunjukkan bahwa benar subjek tidak memeriksa ulang jawabannya kembali (S2W234). Sehingga dapat dikatakan bahwa subjek melakukan kesalahan yaitu penyelesaian tidak diperiksa kembali dalam memecahkan masalah HOTS bidang geometri.

\section{Transkrip 4}

$P \quad: \quad$ Terus kita periksaji ulang ji dek penyelesaianta?

S2-W234 : Tidak sempat ka periksa ulang kak karena habis waktunya. 
Pada Gambar 2, terlihat bahwa dalam menentukan luas segitiga dengan rumus $\frac{a \times t}{2}$ subjek menuliskan $12-\frac{48}{7} \cdot \frac{48}{7}$ yang seharusnya $\frac{\left(12-\frac{48}{7}\right) \cdot \frac{48}{7}}{2}$ (S2T23). Namun setelah dikonfirmasi melalui wawancara, ternyata subjek menyadari kesalahan yang dilakukannya dalam menyelesaiakan soal (Transkrip 5)

\section{Transkrip 5}

P : Nah, coba perhatikan ki cara ta cari luas segitiga. Kenapa $\frac{48}{7} \cdot \frac{48}{7}$ dioperasikan terlebih dahulu?

S2-W225 : Karena kalau ada pengurangan dan perkalian, perkalian yang lebih dulu dikerjakan kak

$P \quad: \quad$ Oh begitu?

S2-W226 : Eh astaga, seharusnya ada tanda kurungnya itu kak $12-\frac{48}{7}$ karena itu alasnya baru dikalikan $\frac{48}{7}$.

Transkrip 5 menunjukkan bahwa benar subjek melakukan kesalahan perhitungan dalam menetukan luas segitiga (S2-W226). Sehingga dapat dikatakan bahwa subjek melakukan kesalahan teknis dalam memecahkan masalah HOTS bidang geometri

\section{Kesalahan Subjek Kemampuan Awal Matematika Rendah}

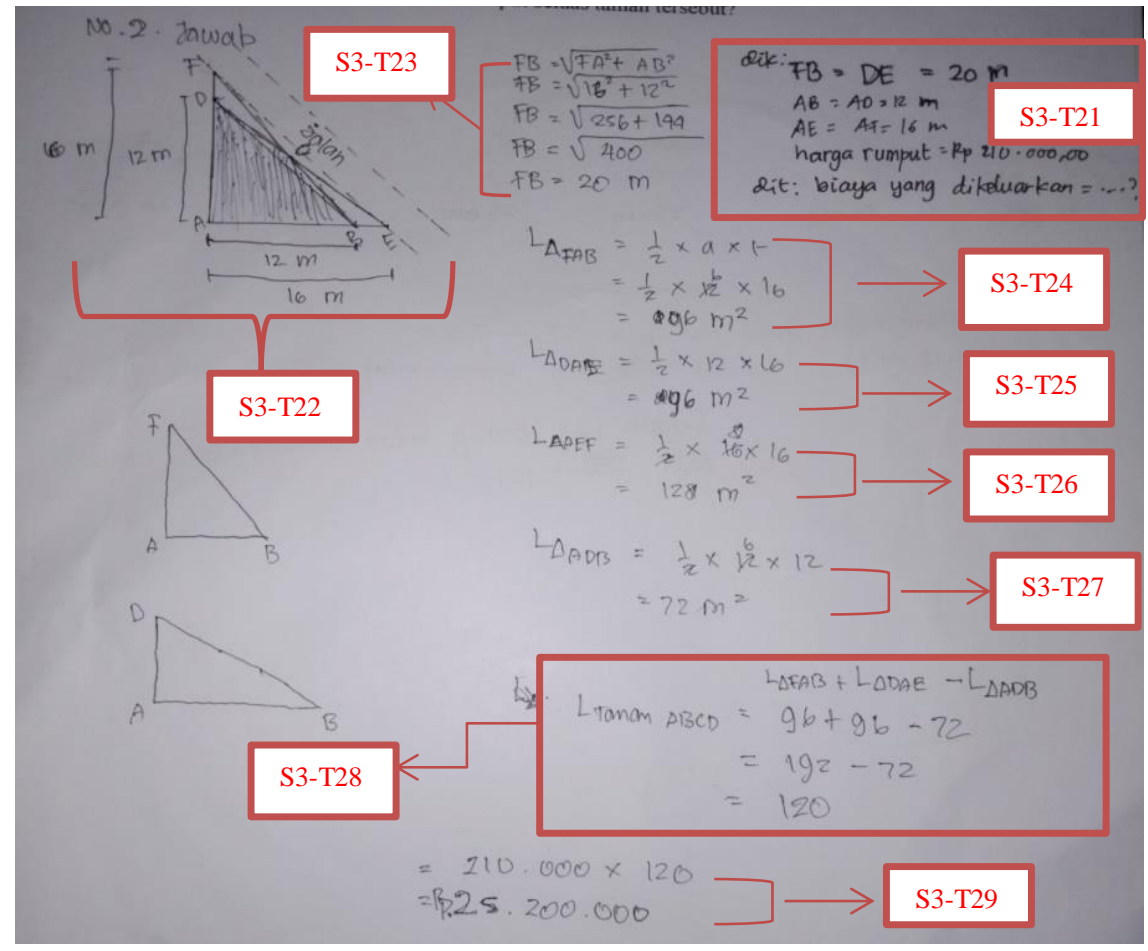

GAMBAR 3. Paparan hasil tes HOTS subjek dengan kemampuan awal matematika rendah (MMAN)

Pada Gambar 3, terlihat bahwa subjek telah menuliskan diketahui dan ditanyakan pada soal (S3-T21)tetapi subjek kurang mampu mengubah informasi yang diketahui dari soal ke dalam model matematika dengan benar sehingga subjek keliru dalam menentukan cara mendapatkan luas bangun segiempat dimana menjumlahkan luas $\triangle F A B, \triangle D A E$ lalu dikurangi dengan luas 
$\triangle A D B$ (S3-T28). Setelah dikonfirmasi melalui wawancara, ternyata subjek tidak menyadari kesalahan dalam menentukan luas bangun segiempat (Transkrip 6)

\begin{tabular}{|c|c|c|}
\hline \multicolumn{3}{|c|}{ Transkrip 6} \\
\hline$P$ & & $\begin{array}{l}\text { Setelah kumpulkan ki informasi yang diketahui dari soal, langkah apa } \\
\text { selanjutnya dek? }\end{array}$ \\
\hline$S 3-W 25$ & $:$ & $\begin{array}{l}\text { Mulai ma hitung ki kak. Pertama yang ku hitung kak jarak antara sudut } \\
F \text { ke E itu } 20 \mathrm{~m} \text {. Yang kedua saya cari luas segitigaFAB jadi } 96 \mathrm{~m}^{2} \text { dan itu } \\
\text { juga sama dengan luas segitiga DAE dimana itu segitiga } F A B \text { memotong } \\
\text { taman itu. Terus saya cari luas segitiga AEF dan hasilnya } 128 \mathrm{~m}^{2} \text {. Lalu } \\
\text { saya kurangi dari jumlah luas segitiga FAB dan luas segitiga DAE dengan } \\
\text { luas segitiga AEF dimana saya dapat itu } 120 \mathrm{~m}^{2} \text {, itu mi kak luasnya taman. } \\
\text { Terus terakhir, saya kali dengan harga rumput dan saya dapat } \\
\text { Rp } 25.200 .000,00 \text {. }\end{array}$ \\
\hline$P$ & . & Jadi, benar mi jawaban ta dek \\
\hline$J$ & ? & Menurutku kak benar mi \\
\hline
\end{tabular}

Transkrip 6 menujukkan bahwa benar subjek tidak menyadari kesalahannya dalam menentukan luas bangun segiempat dan tidak mampu memahami kalimat soal dengan baik sehingga subjek melakukan kesalahan dalam mengubah informasi ke dalam model matematika yang berakibat subjek melakukan kesalahan dalam menentukan luas bangun segiempat dan biaya untuk mebeli rumput yaitu $p 25.200 .000,00$ (S3-W25) yang seharusnya $R p$ 17.280.00,00. Sehingga dapat dikatakan bahwa subjek melakukan kesalahan menginterpretasi bahasa dalam memecahkan masalah HOTS bidang geometri.

Pada Gambar 3, terlihat bahwa subjek awalnya mencari panjang $F B$ menggunakan rumus Phythagoras (S3-T23), kemudian mencari luas segitiga yang ada pada gambar yaitu $\triangle F A B$ (S3$\mathrm{T}$ 24), $\triangle D A E$ (S3-T25), $\triangle A E F$ (S3-T26) dan $\triangle D A B$ (S3-T27). Kemudian menentukan luas bangun segiempat yang diperoleh dari jumlah luas $\triangle F A B$ dan $\triangle D A E$ kemudian dikurangkan dengan luas $\triangle D A B$ (S3-T28) yang seharusnya luas daerah yang diarsir adalah jumlah luas persegi dan luas dua segitiga. Karena kekeliruan subjek dalam menentukan luas bangun segiempat maka subjek pun mendapatkan biaya yang dikeluarkan untuk membeli rumput sebesar $R p 25.200 .00,00$ yang seharusnya $R p 17.280 .00,00$. Setelah dikonfirmasi melalui wawancara subjek tidak menyadari kesalahannya (Transkrip 7)

\section{Transkrip 7}

$P \quad: \quad$ Setelah kumpulkan ki informasi yang diketahui dari soal, langkah apa selanjutnya dek?

S6-W25 : $\quad$ Mulai ma hitung ki kak. Pertama yang ku hitung kak jarak antara sudut $F$ ke E itu $20 \mathrm{~m}$. Yang kedua saya cari luas segitiga FAB jadi $96 \mathrm{~m}^{2}$ dan itu juga sama dengan luas segitiga DAE dimana itu segitiga FAB memotong taman itu. Terus saya cari luas segitiga AEF dan hasilnya $128 \mathrm{~m}^{2}$. Lalu saya kurangi dari jumlah luas segitiga $F A B$ dan luas segitiga DAE dengan luas segitiga AEF dimana saya dapat itu $120 \mathrm{~m}^{2}$, itu mi kak luasnya taman. Terus terakhir, saya kali dengan harga rumput dan saya dapat $R p 25.200 .000,00$.

Transkrip 7 menunjukkan bahwa benar subjek menentukan luas bangun yang diarsir dengan menjumlahkan luas $\triangle F A B$ dan $\triangle D A E$ kemudian dikurangkan dengan luas $\triangle D A B$ dan mendapatkan harga rumput sebesar $R p$ 25.200.000,00 yang seharusnya $R p$ 17.280.00,00. Sehingga dapat dikatakan bahwa subjek melakukan kesalahan menggunakan logika untuk menarik kesimpulan dalam memecahkan masalah HOTS bidang geometri.

Pada Tabel 2, terlihat perbedaan jumlah kesalahan yang dilakukan tiap subjek. S1dengan kemampuan awal tinggi melakukan satu kesalahan yaitu kesalahan teknis. Dibandingkan 
dengan subjek lain, S2 dengan kemampuan awal sedang justru melakukan kesalahan terbanyak dibandingkan dengan S3 dengan kemampuan awal rendah.

TABEL 2. Perbedaan Kesalahan Subjek dalam Memecahkan Soal HOTS Geometri

\begin{tabular}{|c|c|c|c|}
\hline Subjek & \multirow{2}{*}{ S1 } & \multirow{2}{*}{ S2 } & \multirow{2}{*}{ S3 } \\
\hline Jenis Kesalahan & & & \\
\hline Kesalahan Menggunakan Data & - & - & - \\
\hline Kesalahan Menginterpretasikan Bahasa & - & - & $\sqrt{ }$ \\
\hline $\begin{array}{l}\text { Kesalahan Menggunakan Logika Dalam Menarik } \\
\text { Kesimpulan }\end{array}$ & - & $\sqrt{ }$ & $\sqrt{ }$ \\
\hline Kesalahan Menggunakan Definisi atau Teorema & - & $\sqrt{ }$ & - \\
\hline Penyelesaian Tidak Diperiksa Kembali & 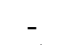 & $\sqrt{ }$ & - \\
\hline Kesalahan Teknis & $\sqrt{ }$ & $\sqrt{ }$ & - \\
\hline
\end{tabular}

\section{KESIMPULAN}

Subjek dengan kemampuan awal tinggi dalam memecahkan masalah matematika HOTS materi geometri tidak melakukan kesalahan sedikit pun dalam menyelesaikan soal tersebut. Subjek dengan kemampuan awal sedang dalam memecahkan masalah matematika HOTS materi geometri melakukan empat jenis kesalahan yaitu (1) kesalahan dalam menggunakan logika untuk menarik kesimpulan (logically invalid inference), (2)kesalahan menggunakan definisi atau teorema (distorted theorem or definition), (3) penyelesaian tidak diperiksa kembali (unverified solution), (4) kesalahan teknis (technical error). Subjek dengan kemampuan awal rendah dalam memecahkan masalah matematika HOTS materi geometri melakukan dua jenis kesalahan yaitu (1) kesalahan menginterpretasi bahasa (misinterpreted language), (2) Kesalahan menggunakan logika untuk menarik kesimpulan (logically invalid inference).Dari hasil pekerjaan dan wawancara siswa, hal ini membuktikan bahwa kesalahan tidak hanya dilakukan oleh siswa berkemampuan awal rendah atau subjek kelompok kesalahan tinggi, tetapi pada siswa berkemampuan awal sedang masih terdapat kesalahan yang dilakukan dalam menyelesaikan soal.

\section{DAFTAR PUSTAKA}

Anderson, L.W., \& Krathwohl, D.R. (2001). A Taxonomy for Learning, Teaching, and Assessing : A Revision of Bloom's Taxonomy of Educational of Objectives (Rev. ed). New York: Addison Wesley.

Anderson, L.W., \& Krathwohl, D.R. (2015). Kerangka Landasan untuk Pembelajaran, Pengajaran, dan Asesmen Revisi Taksonomi Pendidikan Bloom. Terjemahan : Agung Prihantoro. Yogyakarta : Pustaka Belajar.

Bell, F.H. (1978). Teaching and Learning Mathematics in Secondary School. New York : Wm C Brown Company Publisher.

Gais, Z., Afriansyah, E. (2017). Analisis Kemampuan Siswa dalam Menyelesaikan Soal High Order Thinking Ditinjau dari Kemampuan Awal Matematis Siswa. STKIP Garut, 6(2).

Genarsih, T. (2015). Proses Berpikir Reflektif Siswa SMA Dalam Pemecahan Masalah. Jurnal Elektronik Pembelajaran Matematika,3(7).787-795

Gunowibowo, P. (2008). Efektifitas Pendekatan Realistik Dalam Meningkatkan Kemampuan Menyelesaikan Soal Cerita dan Sikap Terhadap Matematika Ditinjau Dari Kemampuan Awal Siswa Kelas IV SD Di Kecamatan Purworejo Kabupaten Purworejo (Tesis). Surakarta.

Hadar, M., Zaslavsky, O., \& Inbar, S. (1987). An Empirical Classification Model For Error in High 
http://links.jstor.org/sici=00219251\%28198701\%2918\%3AI\%3C3\%3AAECMFE\%3E2. 0.CO\%3B2-G diakses pada tanggal 5 Mei 2018.

Hartono, J. (2014). Metode Penelitian Bisnis. Yogyakarta : Universitas Gadjah Mada.

Karso, Suyadi, Muhsetyo, Chadra, Widagdo \& Priatna. (2008). Pendidikan Matematika 1. Jakarta : Universitas Terbuka.

Komarudin. (2016). Analisis Kesalahan Siswa dalam Pemecahan Masalah Matematika pada Materi Peluang berdasarkan High Order Thinking dan Pemberian Scaffolding. Jurnal Institut Agama Islam Darussalam, 8(1).

Krulik, S \& Rudnick. (1999). Innovative Taks to Improve Critical and Creative Thinking Skills. Develoving Mathematical Raesoning in Grades K-12. 138-145.

Kuswana, S.W. (2012). Taksonomi Kognitif. Bandung : PT Remaja R.

Maryam, S. (2016). Representasi Siswa SMP Dalam Menyelesaikan Soal Open-Ended Ditinjau Dari Kemampuan Matematika. Jurnal Ilmiah Pendidikan Matematika.

Miles,H.\&Saldana. (2014). Qualitative Data Analysis. https://books.google.co.id/books?id=pOwXBAAAQBAJ\&printsec $=$ frontcover $\& h l=i d \# v$ $=$ onepage $\& \& f=$ false diakses pada tanggal 5 Mei 2018

Mullis, I.V.V., Martin, M.O., Ruddock, G.J., O’Sullivan, C.Y. \& Preuschoff, C. (2009). TIMMS 2011 Assesment Frameworks. Amsterdam : International Association for the Evaluation of Educational Achievement (IEA).

Polya, G. (1973). How to Solve It. A New Aspect of Mathematical Method. Princeton and Oxford: Princeton University Press.

Priansa, J. D. (2015). Manajemen Peserta Didik dan Model Pembelajaran. Bandung : Alfabeta. Rosnawati. (2005). Pembelajaran Matematika Yang Mengembangkan Berpikir Tingkat Tinggi. Makalah. Disampaikan dalam Seminar Nasional.

Sani, A. R. (2016). Pembelajaran Saintifik untuk Implementasi Kurikulum 2013. Jakarta : Bumi Aksara.

Setiadi, H., \& Mahdiansyah (2012). Kemampuan Matematika Siswa SMP di Indonesia. Jakarta: Pusat Penelitian, Badan Penelitian dan Pengembangan, Kementerian Pendidikan dan Kebudayaan.

Shadiq, F. (2009). Kemahiran Matematika Diklat Instruktur Pengembang Matematika SMA Jenjang Lanjut. Yogyakarta: Depdiknas

Soekamto,T., \& Saripudin, U. (1996). Teori Belajar dan Model-Model Pembelajaran. Jakarta : PAU-PPAI, Universitas Terbuka.

Suharna, Hery, Nusantara, T., Subanji, \& Irawati, S. (2013). Berpikir Reflektif Mahasiswa dalam Menyelesaikan Masalah Matematika. KNPM V, Himpunan Matematika Indonesia, (Online), 1(1), http://fmipa.um.ac.id. diakses 17 juli 2017).

Tambychik, T., Meerah, T. S. M., \& Aziz, Z. (2010). Mathematics Skills Difficulties: A mixture of intricacies. Procedia Social and Behavioral Sciences, 7(C).171-180.

TIM Instruktur Jurusan Matematika. (2008). Model-Model Pembelajaran Inovatif dan Asesmen Pembelajaran Matematika. UNM.

Utari. (2004). Kemandirian Belajar: Apa, Mengapa, dan Bagaimana Dikembangkan Pada Peserta Didik. Yogyakarta : Universitas Negeri Yogyakarta.

Widodo, S. A., \& Sujadi, A. A. (2015). Analisis Kesalahan Mahasiswa dalam Memecahkan Masalah Trigonometri. SOSIOHUMANIORA: Jurnal Ilmiah Ilmu Sosial dan Humaniora, 1(1).

Zaini, M. (5 Mei 2015). Hasil Belajar dan Keterampilan Berpikir Tingkat Tinggi Siswa SMA pada Pembelajaran Biologi Menggunakan Model Pembelajaran Berdasarkan Masalah, 20(207). (online). http://eprints.unlam.ac.id. 